\title{
Viruses, definitions and reality
}

\section{Libia Herrero-Uribe}

Centro de Investigación en Enfermedades Tropicales, Facultad de Microbiología, Universidad de Costa Rica. San José, Costa Rica; libia.herrero@ucr.ac.cr

\author{
Received 26-I-2011. $\quad$ Corrected 15-II-2011. Accepted 03-III-2011.
}

\begin{abstract}
Viruses are known to be abundant, ubiquitous, and to play a very important role in the health and evolution of life organisms. However, most biologists have considered them as entities separate from the realm of life and acting merely as mechanical artifacts that can exchange genes between different organisms. This article reviews some definitions of life organisms to determine if viruses adjust to them, and additionally, considers new discoveries to challenge the present definition of viruses. Definitions of life organisms have been revised in order to validate how viruses fit into them. Viral factories are discussed since these mini-organelles are a good example of the complexity of viral infection, not as a mechanical usurpation of cell structures, but as a driving force leading to the reorganization and modification of cell structures by viral and cell enzymes. New discoveries such as the Mimivirus, its virophage and viruses that produce filamentous tails when outside of their host cell, have stimulated the scientific community to analyze the current definition of viruses. One way to be free for innovation is to learn from life, without rigid mental structures or tied to the past, in order to understand in an integrated view the new discoveries that will be unfolded in future research. Life processes must be looked from the complexity and trans-disciplinarity perspective that includes and accepts the temporality of the active processes of life organisms, their interdependency and interrelation among them and their environment. New insights must be found to redefine life organisms, especially viruses, which still are defined using the same concepts and knowledge of the fifties. Rev. Biol. Trop. 59 (3): 993-998. Epub 2011 September 01.
\end{abstract}

Key words: life organisms, viruses, definitions, new discoveries, challenges, historical views.

"Viruses are Viruses", Lwoff made the most famous definition of viruses in 1957 (Lwoff 1957). Viruses are now known to be abundant, ubiquitous, and to play a very important role in the health of humans, animals, plants and protists; viral genes constitute the largest part of the gene sphere and have probably been crucial for the evolutionary life of the planet. Recent studies (Lindell et al. 2005, Sullivan et al. 2005, Suttle 2005) have revealed the importance of marine viruses in oceanographic processes, since they are the most abundant and diverse "life forms" in the ocean. They are the major pathogens of planktonic organisms and consequently they are significant players in nutrient and energy cycling. Viruses are important pathogens of high animals and the major cause of mortality, and they also are drivers of global geochemical cycles; yet, biological sciences considered them as entities separate from the realm of life and acting merely as mechanical artifacts that can exchange genes between different species, genera, phyla and even from one ecosystem to another (Villarreal 2004, Sullivan et al. 2005, Raoult \& Forterre 2008). One might consider that these statements are in conflict; for this reason, viral characteristics, functions and their intimacy with the web of life led to the revision of some definitions of life organisms to determine if viruses adjust to them, and additionally, new discoveries are considered to challenge the present definition of viruses. 
Lwoff in 1957 wrote that the definition of viruses is somewhat arbitrary, and many definitions have been offered, in itself a proof of the difficulty of the task. He proposed to define viruses as strictly intracellular and potentially pathogenic entities, with an infectious phase, and possessing only one type of nucleic acid, multiplying in the form of their genetic material, unable to grow and to undergo binary fission and devoid of a "Lipmann system" (i.e. a system of enzymes for the production of energy). In his definition, he stresses the noncellular nature of viruses, their dependence on host-cell metabolism and the fact that a specific material of a virus is reduced to an element of genetic material, its nucleic acid.

At that time, viral enzymes had not being discovered with the exception of the neuraminidase of Influenza virus (Gottschalk 1957) and it took a few more years until other viral enzymes were discovered (Baltimore \& Franklin 1963, Baltimore 1970, Temin \& Mizutani 1970). This situation greatly influenced how viruses were defined, since if viruses lacked enzymes it was assumed that the replication cycle of viruses would be quite passive, from the viral point of view, and that the host cells would do all the work.

Intracellular parasitism of viruses is shared with other parasites, including bacteria, fungi and protozoa, but the definitions of viruses stress the intimate nature of viral parasitism, which may be called parasitism at the genetic level. All other parasites have a cellular organization, their need to parasitize other cells from within, probably reflecting the requirement for an exogenous supply of special nutrients, or of metabolic intermediates, rather than their own cellular organization (Luria et al. 1978).

Lwoff (1957) defined living organisms as independent units of integrated and interdependent structures and functions. Hence, he regarded viruses as non-living because he considered them non-organisms. Luria, (Luria 1959) a virologist of the same period, defined an organism as one that presents individuality, historical continuity and evolutionary independence rather than functional independence. Viruses appear to fit this definition.

A few decades later, Harold (1986) stated that living things differ from non-living things in their capacity to maintain, reproduce and multiply states of matter characterized by an extreme degree of organization. As explained below, viruses can modify elements of the host cell such as cell membranes and cytoskeletons, reorganizing them into very specialized structures that will serve as sites of viral replication (Kirkegaard \& Jackson 2005, Novoa et al. 2005, Knoops et al. 2008).

Morowitz (1968) stated that a living organism is one that extracts energy from the environment, uses it to perform all manners of chemical and physical work, and converts energy into organization. Here again, viruses fit this definition since they use all types of structures and processes of the cell, which is its environment, to produce organization.

Characteristics that viruses do not share with other organisms are: they are not cells that are considered the units of life, they depend on a living cell to replicate and they do not harbor metabolic or energy-producing machinery. One can consider viruses as having unique characteristics such as being the world's leading source of genetic innovation and as permanently capable of colonizing their host (Villarreal 2004, Suttle 2005).

The theory of Autopoiesis by Maturama \& Varela (1998) deals with the question "what is life?" and attempts to define, beyond the diversity of all living organisms, a common denominator that allows for the discrimination of the living from the non-living. An autopoiesis system organizes the production of its own components, so that these components are continuously re-generated and the system can therefore maintain the very network process that produces them. Living beings are characterized by their continuous self-production, so they are an autopoietic organization. Even though the theory of autopoiesis is based on cellular life, viruses can fit in this definition since they have their own organization, and viral complexity is reached by viruses within 
and with the cell, through all the interactions occurring between cells and viral proteins that coordinate and rearrange membranes and the cytoskeleton and even the interaction of the infected cell with neighboring cells (Kirkegaard \& Jackson 2005, Novoa et al. 2005, Knoops et al. 2008).

Viruses rely on the host cell infrastructure and metabolism during essentially all stages of their replication cycle, in particular on cell membranes and the cytoskeleton. Therefore, they have adopted strategies to coordinate a variety of molecular interactions in both time and intracellular space. They have the necessary enzymes to modify cell structures and mechanisms for their own benefit (Kopek et al. 2007, Miller \& Krijnse-Locker 2008).

Viral factories are extensive virus-induced reorganizers of host cell membranes transforming them into a network used to promote viral replication and possibly hide replicating RNA from antiviral defense mechanisms, they facilitate the concentration of viral macromolecules and provide a membrane-based structural framework for RNA replication (Novoa et al. 2005, Kopek et al. 2007, Miller \& KrijnseLocker 2008).

Viral factories are very dynamic structures, in which viral and cell factors move in and out depending on the step of the viral life cycle. In viral factories, mitochondria seem to provide the necessary energy for virus morphogenetic processes (Kirkegaard \& Jackson 2005, Novoa et al. 2005, Kopek et al. 2007, Knoops et al. 2008).

All these processes indicate that viruses have evolved elaborate strategies to modify cellular mechanisms that are involved in vesiculation and transport for their own purposes. Although some cellular-interaction partners have been identified, a detailed understanding of the molecular mechanisms of membrane remodeling by viruses is still lacking (Kopek et al. 2007). Non-structural viral proteins can induce alterations of intracellular host cell membrane structures, and can recruit cell components required for viral replication and for membrane bending, thus helping the virus to exit the cell (Novoa et al. 2005, Miller \& Krijnse-Locker 2008).

These are just a few examples of how viruses interfere with very important cellular processes and therefore become an intrinsic part of the cell since they can modify cells and lead them to their death, permanently invade the cell genome, induce a persistent and a latent infection and their presence can produce immune tolerance or autoimmune diseases. Viruses have developed many clever ways to avoid detection by the host immune system - essentially every step in the immune process can be altered or controlled by various genes found in one or another virus (Fairweather 2009).

Raoult et al. (2004) described a giant DNA virus Mimivirus, with unique morphological and genomic characteristics that has been classified as a member of a new distinct Nucleocytoplasmic Large DNA virus family, the Mimiviridae. These viruses, because of their size, the complexity of their genome that harbors three genes for aminoacyl-tRNA synthetases described for the first time in a viral genome and four unique orphan genes, challenges the definition of viruses and even the definition of an organism (Raoult \& Forterre 2008). Suzan-Monti et al. (2006) have recently proposed a new classification of Mimivirus, since its genome revealed features shared with other viral, bacterial or cellular genomes as well as features unique to this virus. The only differences to date between the Mimivirus and small obligate intracellular bacteria are the absence from the virus of ribosomal proteins and of proteins involved in energy metabolism, and multiplication of the virus by assembly of pre-formed subunits.

Häring and collaborators (2008) have described a new virus from a hyperthermophilic archeon growing in acidic hot springs that produces two long filamentous tails once they are outside and independent of their host cell. Results from different experiments have confirmed that tail development is an active biological process and is not the result of particle disruption. 
There are several examples of natural extracellular viral morphogenesis phenomena, but they are believed to occur either at the final steps of the viral cycle namely assembly and maturation (Swanstrom \& Willis 1997, Pettit et al. 2004), or at the initial steps of infection (Ackermann \& Bamford 2000) and they are triggered on the host-cell surface concurrently with virus budding or adsorption respectively.

Rice et al. (2004) described the structure of a thermophilic archaeal virus with a doublestranded DNA and viral capsid that spans all domains of life. By comparing the tertiary and quaternary structures of the coat protein of this virus with those of bacterial and an animal virus, they concluded that some viruses have a common ancestor that precedes the division into the three domains of life more than 3 billion years ago. The recent discovery that the virus factory of Mimivirus can be infected by another virus (Sputnik) has also been taken as an argument in favor of the living nature of viruses (La Scola et al. 2008, Pearson 2008).

Forterre (2010) suggested to define life (an historical process) as a mode of existence of ribosome encoding organisms (cells) and capsid encoding organisms (viruses) and their ancestors; he also concluded that infected eukaryotic cells in which viral factories have taken control of the cellular machinery became viruses themselves, the viral factory being in that case the equivalent of the nucleus. By adopting this viewpoint, one should finally consider viruses as cellular organisms. They are of course a particular form of cellular organism, since they do not encode their own ribosomes and cell membranes, but borrow those from the cells in which they live (Forterre 2010).

Studies on marine viruses (Lindell et al. 2005, Sullivan et al. 2005, Suttle 2005) have brought new discoveries, new mechanisms, an abundant genetic richness; the more research is carried out in unexplored sites and organisms, the more new viruses will be described with new characteristics that will continue to challenge viral definitions.

\section{CONCLUSIONS}

The replication of a virus is not mechanical; instead viruses have evolved to reorganize, coordinate, manipulate, and modify cell structures and processes to their own benefit in order to replicate, evolve and perpetuate. Viruses have developed the necessary enzymatic machinery to reorganize cell structures to replicate themselves and perpetuate their own kind.

Many studies (Villarreal 2004, Lindell et al. 2005, Sullivan et al. 2005, Suttle 2005) suggest that viruses are the masters of evolution and innovation in the web of life. They are the simplest organisms with the capacity of using the lowest energy to conserve life and its diversity. Life has existed for millions of years, and humans depend on newer and more sophisticated technologies to unravel life processes and mechanisms. Thus they should open their minds to the new discoveries and try to innovate definitions, according to the complexity of life itself and not from an anthropocentric point of view.

Forterre's (2010) conclusion that infected eukaryotic cells in which viral factories have taken control of the cellular machinery became viruses themselves, is an affirmation that places itself in the center of the modern paradigm in which the analysis and study of life processes must be looked from the complexity and transdisciplinarity perspective (HerreroUribe 2008) since the analysis includes and accepts the temporality of the active processes of life organisms, their interdependency, and interrelation among themselves and with their environment.

One way to be free for innovation is to learn from life, without rigid mental structures in order to understand in an integrated view the new discoveries that will be unfolded in future research. New insights must be taken to redefine life organisms; especially viruses, which still are defined using the same concepts and knowledge of the fifties. 


\section{ACKNOWLEDGMENTS}

The author is deeply grateful to Anne-Lise Haenni and Laya Hun Opfer for their invaluable support.

\section{RESUMEN}

Los virus son abundantes, ubicuos, y juegan un papel muy importante en la salud y en la evolución de los organismos vivos. Sin embargo, la mayoría de los biólogos los siguen considerado como entidades separadas de la red de la vida y que actúan como meros artefactos mecánicos a la hora de intercambiar genes entre los diferentes organismos. Este artículo revisa varias definiciones de organismos vivos para determinar si los virus se ajustan a ellas, y adicionalmente, considera los nuevos descubrimientos que retan las definiciones actuales de los virus. La fábricas de virus son discutidas ya que estas mini-organelas son un buen ejemplo de la complejidad de las infecciones virales, no como una usurpación mecánica de las estructuras de la célula, pero como una fuerza vital que lleva a la reorganización y la modificación de las estructuras de las células por enzimas celulares y virales. Los nuevos descubrimientos como los Mimivirus, su virófago y virus que producen colas filamentosas cuando se encuentran fuera de la célula, han estimulado a la comunidad científica a analizar la definición actual de los virus. Para la innovación se debe estar libre de estructuras mentales rígidas o apegadas al pasado, para lograr comprender e integrar los nuevos descubrimientos que traerán las investigaciones futuras. Los procesos de la vida deben verse desde la perspectiva de la complejidad y la trans-disciplinariedad que incluye y acepta la temporalidad de los procesos activos de los organismos vivos y su interdependencia e interrelación entre ellos y su ambiente.

Palabras clave: organismos vivos, virus, definiciones, nuevos descubrimientos, visión histórica.

\section{REFERENCES}

Ackermann, H.W. \& D. Bamford. 2000. Seventh report of the international committee on taxonomy of viruses. Academic, London, England.

Baltimore, D \& R.M. Franklin. 1963. A new ribonucleic acid polymerase appearing after mengovirus infection of Hela cells. J. Biol. Chem. 238: 3395-3400.

Baltimore, D. 1970. RNA-dependent DNA polymerase in virions of RNA tumour viruses. Nature 226: 1209-1211.

Fairweather, D. 2009. Alternatively activated macrophages in infection and autoimmunity. J. Autoimmun. 33: 222-230.
Forterre, P. 2010. Defining life: the virus viewpoint. Org. Life Evol. Biosph. 40: 151-160.

Gottschalk, A. 1957. Neuroaminidase: the specific enzyme of influenza virus and Vibrio cholera. Biochim. biophys. Acta 23: 645-646.

Häring, M., G. Vestergaard, R. Rachel, L. Chen, R.A. Garret \& D. Prangishvili. 2008. Independent virus development outside a host. Nature 436: 1101-1102.

Harold, F.M. 1986. The vital force: a study of bioenergetics. W.H. Freemann, New York, USA.

Herrero-Uribe, L. 2008. Del mecanicismo a la complejidad en la biología. Rev. Biol. Trop. 56: 399-407.

Kirkegaard, K. \& W.T. Jackson. 2005. Topology of doublemembrane Vesicles and the opportunity for non-lytic release of cytoplasm. Autophagy 1: 182-184.

Knoops, K., M. Kikkert, S.H.E. van den Worm, J.C. Zevenhoven-Dobbe, Y. van der Meer, A.J. Koster, A.M. Mommaas \& E.J. Snijder. 2008. SARS-coronavirus replication is supported by a reticulovesicular network of modified endoplasmic reticulum. PLoS Biol. 6: 1957-1961.

Kopek, B.G., G. Perkins, D.J. Miller, M.H. Ellisman \& P. Ahlquist. 2007. Three-dimensional analysis of a viral RNA replication complex reveals a virus-induced mini-organelle. PLoS Biol. 5: 2022-2034.

La Scola, B., C. Desneu, P. Pagnier, C. Robert, L. Barrasi, G. Fournous, M. Merchat, M. Suzan-Monti, P. Forterre, E. Koonin \& D. Raoult. 2008. The virophage, a unique parasite of the giant Mimivirus. Nature 45: 100-104.

Lindell, D., J.D. Jaffe, Z.I. Johnson, G.M. Church \& S. Chisholm. 2005. Photosynthesis genes in marine viruses yield proteins during host infection. Nature 438: 86-89.

Luria, S.E. 1959. Viruses as infective genetic materials, p. 188-195. In V. Najjar (ed.). Immunity and virus infection. Wiley, New York, USA.

Luria, S.E., J.E. Jr. Darnell, D. Baltimore \& A. Campbell. 1978. General virology. Wiley, New York, USA.

Lwoff, A. 1957. The concept of virus. J. Gen. Microbiol. 17: 239-253.

Maturana, H.R. \& F.J. Varela. 1998. The tree of knowledge. Shambhala, Boston, London, England.

Miller, S. \& J. Krijnse-Locker. 2008. Modification of intracellular membrane structures for virus replication. Nature Rev. Microbiol. 6: 363-374. 
Morowitz, H.J. 1968. Energy flow in biology: biological organization as a problem in thermal physics. Academic, New York, USA.

Novoa, R.R., G. Calderita, R. Arranz, J. Fontana, H. Granzow \& C. Risco. 2005. Virus factories: associations of cell organelles for viral replication and morphogenesis. Biol. Cell. 97: 147-172.

Pearson, H. 2008. Virophage suggests viruses are alive. Nature 454: 677.

Pettit, S.C., L.E. Everitt, S. Choudhury, B.M. Dunn \& A.H. Kaplan. 2004. Initial cleavage of the human immune deficiency virus Type $1 \mathrm{GagPol}$ precursors by its activated protease occurs by an intramolecular mechanism. J. Virol. 78: 8477-8485.

Raoult, D. \& P. Forterre. 2008. Redefining viruses: lessons from Mimivirus. Nature 6: 315-319.

Raoult, D., S. Audic, C. Robert, C. Abergel, P. Renesto, H. Agata, B. La Scola, M. Suzan \& J.M. Claverie. 2004 The 1.2 megabase genome sequence of Mimivirus. Science 306: 1344-1350.

Rice, G., L. Tang, K. Stedman, F. Robert, J. Spuhler, E. Gillitzer, J.E. Johnson, T. Douglas \& M. Young.
2004. The structure of a thermophilic archaeal virus shows a double-stranded DNA viral capsid type that spans all domains of life. PNAS 101: 7716-7720.

Sullivan, M., M. Coleman, P. Weigele, F. Rohwer \& S. Chisholm. 2005. Three Prochlorococcus cyanophage genomes: Signature features and ecological interpretation. PLoS Biol 3: 791-806.

Suttle, C.A. 2005. Viruses in the sea. Nature 437: 356-361.

Suzan-Monti, M., B. La Scola \& D. Raoult. 2006. Genomic and evolutionary aspects of Mimivirus. Virus Res. 117: 145-155.

Swanstrom, R. \& J.W. Willis. 1997. Synthesis, assembly, and processing of viral proteins, p. 263-364. In J.M. Coffin, S.H. Hughes \& H.E. Varmus (eds.). Retroviruses. Cold Spring Harbor Lab, New York, USA.

Temin, H.M. \& S. Mizutani. 1970. RNA-dependent DNA polymerase in virions of Rous sarcoma virus. Nature 226: 1211-1213.

Villarreal, L.P. 2004. Are viruses alive? Sci. Am. 291: 101-105. 